\title{
Immune Checkpoint Inhibitor
}

National Cancer Institute

\section{Source}

National Cancer Institute. Immune Checkpoint Inhibitor. NCI Thesaurus. Code C143250.

An agent that inhibits any of the immune checkpoint inhibitory proteins. 